\author{
О. Г.Розгон \\ orcid.org/0000-0003-3902-7967 \\ кандидат юридичних наук, \\ доцент кафедри адміністративного права, процесу та адміністративної діяльності \\ Дніпропетровського державного університету внутрішніх справ
}

\title{
ІМІДЖ ПОЛІЦЕЙСЬКОГО ЯК СКЛАДНИК ЙОГО ПРОФЕСІЙНОЇ ДІЯЛЬНОСТІ
}

Актуальність теми. Без перебільшення можна сказати, що майже кожна людина на території України мала різні суспільні відносини з поліцейськими. Через значний обсяг виконуваних завдань Національна поліція України перебуває у постійному діалозі з громадянами. Тому серед всіх державних органів поліція є найбільш соціально доступною правоохоронною установою.

Під час реалізації реформи МВС України та Національної поліції України відбулася спроба відкорегувати образ поліцейського. Особливо яскраво можна прослідкувати механізми впровадження позитивного іміджу поліцейського під час формування у 2014 році нового підрозділу поліції - патрульної поліції. Результати такої діяльності дотепер мають свій відгук, адже статистичні показники соціологічних досліджень свідчать, що рівень довіри до патрульних поліцейських завжди вищий, ніж до інших підрозділів Національної поліції України.

Постановка проблеми. За результатами проведення соціологічних досліджень станом на грудень 2020 року не довіряють Національній поліції України 52\% опитаних [1]. Такі цифри вражають, адже від ефективності діяльності силового відомства залежить стабільність і правопорядок у державі. Одним із факторів, які впливають на рівень довіри населення до Національної поліції України, а отже і на ставлення до поліцейських, є імідж поліцейського. У громадян нашої держави відбулося часткове перенесення стереотипу, який складався роками, у ставленні до працівників міліції на поліцейських. Тому подолання сталих кліше є основним завданням керівництва Національної поліції України.

Стан дослідження проблеми. Роботи, присвячені дослідженню іміджу поліції (міліції) України, неодноразово проводили вітчизняні вчені різних галузей науки: В.О. Болотова, І.В. Воробйова, Ю.О. Легеза, Н.С. Малушкіна, С.Л. Недов, В.І. Олефір, Г.О. Пономаренко, О.Л. Порфімович, А.М. Сарвас, В.М. Столбовий, А.С. Токарська, П.П. Френюк, О.М. Чукаєва, О.Ф. Юрчук та інші. Однак після 2014 року відбулися певні зміни іміджу поліцейського, а стрімкий розвиток сучасного суспільства потребує свіжого погляду на вказане явище з урахуванням нинішніх обставин.
Метою статті є з'ясування змісту іміджу поліцейського як складника його професійної діяльності. Для досягнення поставленої мети ми виокремили такі завдання: з'ясувати зміст поняття «імідж поліцейського»; визначити, як саме співвідносяться між собою поняття «імідж» та «професійна діяльність»; виділити складники іміджу поліцейського; запропонувати дієві напрями формування позитивного іміджу поліцейського.

Виклад основного матеріалу. Більшість авторів дотримуються думки, що «образ» є українським еквівалентом англійського слова «імідж». Річ у тім, що термін «імідж» англійською мовою означає «образ, уявлення, зображення». Тлумачний словник української мови трактуе поняття «імідж» як громадську думку, уявлення про когось, щось; репутацію, образ; а також як образ особи (зокрема, її вигляд і манеру поведінки), спрямований на формування громадської думки чи уявлення про неї [5]. На нашу думку, імідж варто розглядати як цілісний, конкретний образ суб'єкта, який чітко відтворюється у громадській свідомості.

Під час формування позитивного іміджу Національної поліції України доцільно використовувати такі методи адміністративного права: переконання, виховання, особистий приклад, опитування громадської думки. Найтісніше імідж пов'язаний із такими формами переконання, як особистий приклад і виховання [4, с. 3-9]. Під переконанням розуміють способи, прийоми, засоби, які використовуються для досягнення поставленої мети; імідж є образом, що складається в суспільній свідомості, уявленням, розумінням, оцінюванням громадянами діяльності поліції [4, с. 3-9]. Розвиваючи думку, висловлену Мироненко Т.Є., що метод переконання та імідж співвідносяться між собою, як діяльність і наслідки такої діяльності, як процес і результат [4, с. 3-9], можемо стверджувати, що імідж поліцейського $€$ результатом його професійної діяльності.

Одночасно погоджуємося $з$ думкою В.М. Столбового та підтримуємо його державно-управлінський підхід до розуміння сутності поняття «імідж». Даний підхід сформувався під впливом ціннісного й етичного підходів, що зумовлюе подвійне розуміння його сутності: з одного боку, імідж є засобом впливу на суспільну свідомість 
з метою підвищення авторитету й довіри до певного державного органу, з іншого - слугує засобом підвищення ефективності діяльності цього органу, що досягається шляхом внутрішнього усвідомлення і прийняття публічно задекларованих цілей і цінностей працівниками цього органу [2]. Тобто, можемо стверджувати, що значення даного явища для Національної поліції України являється ключовим в умовах сьогодення. А запровадження технологій позитивного іміджу Національної поліції України є шляхом, як до зміни ставлення громадян до поліції, так і до підвищення ефективності діяльності поліції в цілому. Такі явища є взаємопов'язаними та взаємозалежними.

Розуміючи сутність явища іміджу в цілому, з метою виділення в подальшому напрямків його формування пропонуємо виділити п'ять основних складових іміджу сучасного поліцейського. Розглянемо їх детальніше.

Зовнішній вигляд (одяг, зачіска, аксесуари та атрибути) є першим фактором, за яким люди приймають рішення про особу, в тому числі і про поліцейського. Відповідно до підпункту 9 пункту 1 розділу II Правил етичної поведінки поліцейських під час виконання службових обов'язків поліцейський повинен мати охайний зовнішній вигляд, бути у встановленій формі одягу [3].

Відсутність можливості урізноманітнити свій зовнішній вигляд, обгрунтоване обов'язком носіння форми та дотриманням встановлених нормативно-правовими актами правил, відіграє лише позитивну роль. Носіння форми викликає у громадян серйозне ставлення до особи поліцейського та вчинюваних ним дій, поважне відношення до представника влади. Відсутність форменого одягу, неакуратні речі або досить вільний вигляд одягу поліцейського відіграють прямо протилежну роль - відбувається порушення сприйняття поліцейського як суб'єкта владних повноважень, накладається образ звичайного громадянина, що, як правило, негативно впливає на виконання професійних функцій. Звичайно, виключенням є виконання поліцейськими оперативних завдань, що потребують злиття з громадою, не передбачають розкриття особи поліцейського.

Сучасним трендом, особливо після реформи МВС України 2014 року, стало носіння поліцейськими вусів та бороди, а також наявність на видимих місцях тіла татуювань. Зважаючи на вимоги сьогодення, зазначені нами та інші особливості зовнішності не впливають на ставлення громадян до поліцейських та дозволені керівництвом Національної поліції України. Проте вимога до них залишається нормативно-визначеною - вони повинні мати охайний вигляд.

Етична поведінка $€$ наступною складовою іміджу, які ми виділяємо. Варто зазначити, що врегулювання діяльності державних структур у демократичній правовій державі неможливе без затвердження етичних норм. Так, загальні засади етичної поведінки поліцейських в Україні визначені у Наказі МВС України «Про затвердження Правил етичної поведінки поліцейських» від 09.11.2016 № 1179 [3]. Затверджені Правила $€$ узагальненим зібранням професійно-етичних вимог щодо правил поведінки поліцейських та спрямовані на забезпечення служіння поліції суспільству шляхом забезпечення охорони прав i свобод людини, протидії злочинності, підтримання публічної безпеки і порядку на засадах етики та загальнолюдських цінностей [3]. Порушення визначених етичних норм може тягнути за собою різні види юридичної відповідальності у випадку наявності складу конкретного правопорушення. Водночас цікаво те, що в поліції відсутні технології оцінювання кадрів, на підставі яких можна було б визначити етичний рівень поліцейського. Запровадження та розвиток високих стандартів етичної поведінки серед поліцейських - важливий елемент їх позитивного іміджу.

Комунікативність, а точніше професійна комунікація поліцейського так само є невід'ємною складовою іміджу поліцейського, адже лише через спілкування поліцейського 3 окремими громадянами або їх колективами можливе виконання професійних обов' язків ефективно. Професійна комунікація поліцейського проявляється в наявності у нього здатності вступати в психологічний контакт з громадянами, формування довірливих відносин у зоні взаємодії, засновані на згоді та взаємному сприйнятті, забезпечення володіння навичками та вміннями спілкування та саморегуляції, а також сприятливими контакту властивостями особистості.

Комунікативність - це властивість особистості, її вроджена можливість вільно спілкуватися з людьми, але професійну комунікацію можливо та потрібно розвивати кожному поліцейському, незалежно від його особистісних характеристик, шляхом відвідування тренінгів особистісного зростання, застосування комунікативних вправ та інших способів саморозвитку. Професійна комунікативна культура є умовою та підставою для ефективної професійної діяльності, показником професійної компетентності та професійного самовдосконалення. Тобто, набуття професійних комунікативних знань, умінь та навичок є обов'язковим елементом формування позитивного іміджу поліцейського, адже безпосередньо в процесі ділового спілкування поліцейського та громадянина останній створює образ поліцейського.

Професіоналізм поліцейського, як елемент іміджу поліцейського, - це багатогранне явище, яке включає:

- відповідність професійної підготовки поліцейського (отримана професійна освіта, проход- 
ження курсів початкової підготовки, проходження курсів підвищення кваліфікації, проходження додаткових курсів з метою розвитку професійних знань, умінь та навичок) набутим компетенціям;

- наявність навичок застосування набутих професійних знань на практиці;

- наявність внутрішнього ставлення поліцейського до вчинюваних ним професійних дій, як до дій, вчинюваних в інтересах Національної поліції України, в інтересах держави в цілому.

У зв'язку з цим актуальним $є$ питання підтримання професійного рівня поліцейського впродовж всього строку служби. Ми виділяємо декілька способів професійного розвитку поліцейських: формальний, тобто нормативно-визначений (курси підвищення кваліфікації, спеціалізація, службова підготовка, тощо) та неформальний, тобто нормативно не визначений, наприклад, обмін досвідом між поліцейськими (як у межах одного підрозділу, так і між підрозділами; як між поліцейськими, що займають рівнозначні посади, так і між начальником та підлеглим), відвідування курсів особистісного росту, саморозвиток, участь у різних державних програмах, акціях, тощо. Процес професійного розвитку має бути постійним та регулярним з метою відповідності вимогам сьогодення, які висуваються до поліцейських громадою.

Невід'ємною частиною сучасного світу є діджиталізація всіх форм суспільного життя. Особливо гостро потреба тотальної діджиталізації стала наявною в умовах запровадження карантинних заходів у 2020 році. Застосування за можливістю електронних ресурсів відбувається в Національній поліції України шляхом впровадження мобільних додатків, вироблення механізмів оплати штрафів, подання звернень онлайн, удосконалення діяльності call-центрів поліції, та інше. Саме тому сучасний поліцейський має вільно орієнтуватися в поліцейських мобільних додатках, бути обізнаним і вміти застосовувати їх у професійній діяльності. Оперативне вирішення поставлених завдань за допомогою електронних ресурсів та гаджетів позитивно впливає на ефективність діяльності Національної поліції, а відповідно і на її результат - позитивний імідж поліцейських.

Формування позитивного стереотипу у ставленні до поліцейських, на наш погляд, може бути реалізовано за допомогою трьох основних напрямків: інформування, переконання та зміна поведінки. Конкретні кроки даних напрямків пропонуємо визначити та затвердити на нормативно-правовому рівні, а саме у Стратегії формування позитивного іміджу Національної поліції України 2021-2026, затвердженій наказом МВС України.

У зв'язку з тим, що громадська думка є основним критерієм оцінки діяльності поліції, співробітники відділів зв'язків з громадськістю Національної поліції України розміщують до- стовірну інформацію про результати діяльності поліцейських в засобах масової інформації. Слід зазначити, що інформація про поліцію сьогодні відрізняється від тієї, яка з'являлася в засобах масової інформації про міліцію, тому що поліція стає іншою. Відкрита інформаційна політика дозволяє інформувати професійно і об’єктивно. Це, безсумнівно, призведе до позитивного результату i сприятиме поліпшенню відносин між цим державним органом і суспільством, а також формуванню позитивного іміджу поліцейського.

Слід зазначити, що істотна роль у формуванні позитивного іміджу поліції, безсумнівно, відноситься до якісному змісту тієї інформації, яка надходить із зовнішнього і внутрішнього середовища поліції. Зрозуміло, в цьому випадку інформація надається через офіційні повідомлення, i вона зазвичай регулюється, але в кінці кінців поліція є особливим органом, i, відповідно, при поданні інформації громадськості неможливо дозволити використання чуток і брехні, оскільки це визначає рівень довіри до поліції і громадському думку про діяльність співробітників структурних підрозділів.

Переконання, як напрям формування позитивного іміджу Національної поліції України, проявляється в діях поліцейських, під час спілкування 3 громадянами, проведення роз'яснювальних бесід, виступів у засобах інформації. Під час переконання слід надати громаді упевненість у надійності самого органу Національної поліції та кожного поліцейського, їх компетентності та прогресивності. Крім того, має бути зроблено акцент на соціальній значимості даного правоохоронного органу.

I, звісно, формування позитивного іміджу поліцейського неможливе без зміни свідомості та поведінки самих поліцейських. Досягнення такого результату можливе через якісний відбір кадрів під час прийому на службу та подальший їх моніторинг. Запровадження чіткої корпоративної етики, що вже відбулося, та подальший жорсткий контроль дотримання нормативно-визначених стандартів поведінки поліцейських. Також, як засіб зміни поведінки поліцейських, вважаємо створення належним умов роботи поліцейських, а також проведення регулярних консультацій 3 психологами всіх поліцейських впродовж служби.

Висновки. Підсумовуючи, сказане, можна зробити висновок про те, що імідж поліцейського це комплексне динамічне явище, яке потребує постійного удосконалення. Дане поняття являє собою внутрішнє уявлення громадян про поліцейських та їх ставлення до них. Постійне удосконалення механізмів формування позитивного іміджу поліцейського необхідне для підвищення соціального довіри, яка може знизити рівень невизначеності у відносинах між громадянами держави і поліцейськими. 


\section{Jimepamypa}

1. Україна-2020: невиправдані очікування, неочікувані виклики. Підсулки року у дзеркалі громад ської думки (грудень 2020p.). URL: https://razumkov. org.ua/napriamky/sotsiologichni-doslidzhennia/ ukraina2020-nevypravdani-ochikuvannia-neochikuvanivyklyky-pidsumky-roku-u-dzerkali-gromadskoi-dumkygruden-2020r.

2. Вільний тлумачний словник. Новітній онлай новий словник української мови (2013-2018). URL: http://sum.in.ua/f/imidzh.

3. Мироненко Т.Є. Підвищення іміджу органів прокуратури серед населення як умова вдосконалення їх взаємодії з громадськістю. Південноукраїнський правничий часопис Одеського державного університету внутрішніх справ. 2008. № 1. С. 3-9.

4. Столбовий В.М. Імідж Національної поліції як суб'єкта службових відносин у сфері національної безпеки України. Порівняльно-аналітичне право. 2018. № 2. С. 273-275.

5. Про затвердження Правил етичної поведінки поліцейських: наказ МВC України від 09.11.2016 № 1179. URL: https://zakon.rada.gov.ua/laws/show/ z1576-16\#Text.

\section{Анотація}

Розгон О. Г. Імідж поліцейського як складник його професійної діяльності. - Стаття.

Метою написання наукової статті є з'ясування змісту іміджу поліцейського, як складової його професійної діяльності. Для досягнення поставленої мети автор виокремлює наступні завдання: з'ясувати зміст поняття «імідж поліцейського»; визначити, як саме співвідносяться між собою поняття «імідж» та «професійна діяльність»; виділити складові іміджу поліцейського; запропонувати дієві напрямки формування позитивного іміджу поліцейського.

В роботі запропоновано імідж розглядати як цілісний, конкретний образ суб'єкта, який чітко відтворюється у громадській свідомості. Автор робить висновок, що імідж поліцейського є результатом його професійної діяльності.

Автор виділяє п'ять основних складових іміджу сучасного поліцейського: зовнішній вигляд (охайний зовнішній вигляд, бути у встановленій формі одягу); етична поведінка (загальні засади етичної поведінки поліцейських в Україні визначені у Наказі МВС України «Про затвердження Правил етичної поведінки поліцейських" від 09.11.2016 № 1179); комунікативність, а точніше професійна комунікація поліцейського (здатність вступати в психологічний контакт 3 громадянами, формування довірливих відносин у зоні взаємодії, засновані на згоді та взаємному сприйнятті, забезпечення володіння навичками та вміннями спілкування та саморегуляції, а також сприятливими контакту властивостями особистості); професіоналізм поліцейського (відповідність професійної підготовки поліцейського набутим компетенціям; наявність навичок застосування набутих професійних знань на практиці; наявність внутрішнього ставлення поліцейського до вчинюваних ним професійних дій, як до дій, вчинюваних в інтересах Національної поліції України, в інтересах держави в цілому); діджиталізація поліцейської діяльності.

Автор виділяє три основних напрямки формування позитивного іміджу поліцейського: інформування, переконання та зміна поведінки. Конкретні кроки даних напрямків запропоновано визначити та затвердити на нормативно-правовому рівні, а саме у Стратегії формуванняпозитивногоіміджуНаціональноїполіціїУкраїни 2021-2026, затвердженій наказом МВС України.

Ключові слова: імідж, поліція, поліцейський, ефективність, фактори, етична поведінка, комунікативність, діджиталізація.

\section{Summary}

Rozgon O. G. The image of a police officer is a component of his professional activity. - Article.

The purpose of writing a scientific article is to clarify the content of the image of a police officer as part of his professional activity. To achieve this purpose, the author defines the following tasks: to clarify the meaning of the concept of "police image"; determine exactly how the concepts of "image" and "professional activity" relate to each other; identify components of the image of a police officer; to suggest effective directions of forming a positive image of a police officer.

The paper proposes to consider the image as a holistic, specific image of the subject, which is clearly reproduced in the public consciousness. The author concludes that the image of a police officer is the result of his professional activity.

The author identifies five main components of the image of a modern police officer: appearance (neat appearance, to be in the prescribed form of clothing); ethical conduct (general principles of ethical conduct of police officers in Ukraine are defined in the Order of the Ministry of Internal Affairs of Ukraine "About approval of the Rules of ethical conduct of police officers" 09.11.2016 № 1179); communication, or rather professional communication of a police officer (ability to enter into psychological contact with citizens, the formation of trusting relationships in the area of interaction, based on consent and mutual perception, ensuring communication skills and self-regulation, as well as favorable contact personality traits); professionalism of a police officer (compliance of professional training of a police officer with acquired competencies; availability of skills to apply the acquired professional knowledge in practice; availability of skills to apply the acquired professional knowledge in practice; the presence of the internal attitude of the police officer to his professional actions, as to the actions committed in the interests of the $\mathrm{Na}$ tional Police of Ukraine, in the interests of the state as a whole); digitalization of policing.

The author identifies three main areas of forming a positive image of the police: informing, persuasion and behavior change. It is proposed to define and approve specific steps in these areas at the regulatory level, namely in the Strategy for the formation of a positive image of the National Police of Ukraine 2021-2026, approved by the order of the Ministry of Internal Affairs of Ukraine.

Key words: image, police, police officer, efficiency, factors, ethical behavior, communication, digitalization. 